\title{
Non-lead ammunition may reduce lead levels in wild game
}

\author{
Eric J Buenz ${ }^{1}$
}

Received: 25 May 2016 / Accepted: 1 June 2016 /Published online: 8 June 2016

(C) Springer-Verlag Berlin Heidelberg 2016

Lehel et al. (2016) provide important data regarding the levels of toxic metals in deer meat. As the authors highlight, there is reason for concern regarding lead levels in wild game relative to the European Union standards. Some of this lead exposure is inevitable as the source is environmental; however, some is anthropogenic and avoidable. The authors did not share that a portion of this anthropogenic lead exposure is likely preventable by using non-lead ammunition to harvest the wild game (Buenz 2016).

Other studies have shown that individuals harvesting wild game with lead bullets have elevated blood lead levels, and isotope analyses have linked bullets to these elevated blood lead levels (Tsuji et al. 2009; Tsuji et al. 2008). Importantly, all the studies to date have established correlations, and a prospective study is necessary. Nonetheless, we should be pragmatic. Just as the parachute has never been proven to be effective in a doubleblind placebo-controlled study (Smith and Pell 2003), I suggest that high-velocity injection and fragmentation (Knott et al. 2010) of a heavy metal into something that is going to be eaten is unwise and should be avoided if possible.

The World Health Organization has taken the position that there is no safe level of lead exposure (WHO 2009). Thus, any steps available to reduce the potential risk of lead exposure are reasonable to implement, particularly when non-lead ammunition is readily available (Kanstrup et al. 2016).

Responsible editor: Philippe Garrigues

Eric J Buenz

Eric.Buenz@nmit.ac.nz

1 Nelson Marlborough Institute of Technology, 322 Hardy Street, Nelson 7010, New Zealand

\section{References}

Buenz EJ (2016) Lead exposure through eating wild game. Am J Med 129:457-458

Kanstrup N, Thomas VG, Krone O, Gremse C (2016) The transition to non-lead rifle ammunition in Denmark: national obligations and policy considerations. Ambio In Press

Knott J, Gilbert J, Hoccom DG, Green RE (2010) Implications for wildlife and humans of dietary exposure to lead from fragments of lead rifle bullets in deer shot in the UK. Sci Total Environ 409:95-99

Lehel J, Laczay P, Gyurcso A, Janoska F, Majoros S, Lanyi K, Marosan M (2016) Toxic heavy metals in the muscle of roe deer (Capreolus capreolus) - food toxicological significance. Environ Sci Pollut Res Int 23:4465-4472

Smith GC, Pell JP (2003) Parachute use to prevent death and major trauma related to gravitational challenge: systematic review of randomised controlled trials. BMJ 327:1459-1461

Tsuji LJ, Wainman BC, Martin ID, Sutherland C, Weber JP, Dumas P, Nieboer E (2008) Lead shot contribution to blood lead of first nations people: the use of lead isotopes to identify the source of exposure. Sci Total Environ 405:180-185

Tsuji LJ, Wainman BC, Jayasinghe RK, VanSpronsen EP, Liberda EN (2009) Determining tissue-lead levels in large game mammals harvested with lead bullets: human health concerns. Bull Environ Contam Toxicol 82:435-439

WHO (2009) Lead Exposure. In: Ezzati M, Lopez AD, Rodgers A, Murray CJL (eds) Comparative quantification of health risks. World Health Organization, Geneva 